\title{
Effects of Ethinylestradiol/Cyproterone Acetate and Ethinylestradiol/Desogestrel Alone and in Combination with Low-Dose Metformin on Glucose and Lipid Homeostasis and Androgenic Hormone Profile in Hirsute Women with Polycystic Ovary Syndrome: A Randomized, Double-Blind, Triple-Dummy Study
}

\author{
Sanjeewani Fonseka ${ }^{*}$ (1), Dilan D. J. Bandara1, Chandrika N. Wijeyaratne ${ }^{2}$, \\ Indika B. Gawarammana', Nishan S. Kalupahana', Shanthini Rosairo', Ranjith Kumarasiri1 \\ ${ }^{1}$ Faculty of Medicine, University of Peradeniya, Peradeniya, Sri Lanka \\ ${ }^{2}$ Department of Obstetrics and Gynaecology, Faculty of Medicine, University of Colombo, Colombo, Sri Lanka \\ Email: *sanjeewani.fonseka@yahoo.com
}

How to cite this paper: Fonseka, S., Bandara, D.D.J., Wijeyaratne, C.N., Gawarammana, I.B., Kalupahana, N.S., Rosairo, S. and Kumarasiri, R. (2019) Effects of Ethinylestradiol/Cyproterone Acetate and Ethinylestradiol/Desogestrel Alone and in Combination with Low-Dose Metformin on Glucose and Lipid Homeostasis and Androgenic Hormone Profile in Hirsute Women with Polycystic Ovary Syndrome: A Randomized, Double-Blind, Triple-Dummy Study. Journal of Biosciences and Medicines, 7, 13-26.

https://doi.org/10.4236/jbm.2019.78002

Received: July 13, 2019

Accepted: August 11, 2019

Published: August 14, 2019

\begin{abstract}
Background: The effects of combined oral contraceptive pills and metformin on glucose and lipid metabolism and androgenic hormone profile of hirsute women with polycystic ovary syndrome (PCOS) are not clearly known. Aims: To determine the effect of ethinylestradiol (35 microg)/cyproterone acetate (2 $\mathrm{mg})(\mathrm{EE} / \mathrm{CPA})$ and ethinylestradiol $(20 \mathrm{microg}) /$ desogestrel $0.15 \mathrm{mg}$ (EE/DES) alone and in combination with metformin on glucose and lipid metabolism and androgenic hormone profile in hirsute women with PCOS. Settings and Design: This randomised, double-blind, triple dummy study was conducted at the Department of Pharmacology, Faulty of Science, University of Peradeniya, Sri Lanka. Methods and Material: A total of 107 patients with PCOS (Rotterdam Consensus Conference Criteria 2003) having hirsutism of 8 or more in the modified Ferriman-Gallwey Score (mFGS), were randomised to receive four drug therapies (arm A: EE/CPA, arm B: EE/DES, arm C: $\mathrm{EE} / \mathrm{CPA}$ plus metformin, arm D: EE/DES plus metformin). Body mass index, fasting plasma glucose, area under the curve of the oral glucose tolerance test, fasting serum insulin, serum leptin, fasting lipids, serum total testosterone, serum sex hormone-binding globulin were determined at initiation and 12 months. Homeostasis model assessment of beta cell function (HOMA- $\beta$ ),
\end{abstract}


Copyright @ 2019 by author(s) and Scientific Research Publishing Inc. This work is licensed under the Creative Commons Attribution International License (CC BY 4.0).

http://creativecommons.org/licenses/by/4.0/ homeostasis model assessment-estimated insulin resistance (HOMA-IR) and free androgen index were calculated. Statistical analysis was done with two ways ANOVA. Results: There was no significant difference in outcome measures at 12 months between the treatment arms. Within the treatment arms, there was reduction of HOMA- $\beta$ in arm B, serum leptin in arm C, $\mathrm{CHO} / \mathrm{HDL}$ ratio in arm $\mathrm{D}$ and an increase in total cholesterol and LDL-cholesterol in arms B and C. Conclusions: EE/DES and EE/CPA with and without low-dose metformin did not have a significant overall effect on glucose and lipid metabolism and androgenic hormonal profile in hirsute women with PCOS. However, desogestrel has reduced the beta-cell function and both desogestrel and cyproterone have adversely affected the lipids.

\section{Keywords}

Polycystic Ovary Syndrome, Ethinylestradiol, Cyproterone Acetate, Desogestrel, Metformin

\section{Introduction}

This Polycystic ovary syndrome (PCOS) is a common disorder affecting women with diverse hormonal and metabolic abnormalities. It is characterized by irregular menstruation, hyperandrogenism and polycystic ovaries. Impaired glucose tolerance and unfavourable lipid profile with increased risk of atherosclerosis are well-known to be associated with PCOS [1].

Insulin resistance and impaired pancreatic beta-cell function have been reported in women with PCOS [2]. Homeostasis model assessment (HOMA) is an index related to glucose homeostasis calculated using fasting insulin and glucose. It is an estimate of patient's hepatic glucose output and pancreatic $\beta$-cell function. The homeostasis model assessment-estimated insulin resistance (HOMA-IR) index is a measure of insulin resistance whereas the HOMA of $\beta$-cell function (HOMA- $\beta$ ) index is a measure of $\beta$-cell function [3]. High HOMA-IR and low HOMA- $\beta$ are associated with impaired glucose tolerance.

Women with PCOS often have higher serum leptin levels than expected for their body mass index (BMI) [4]. Insulin resistance is associated with elevated plasma insulin and leptin levels.

Elevated plasma free testosterone level is also a characteristic feature of PCOS [5]. As direct assays of free testosterone are not reliable, free androgen index is calculated from total testosterone and sex hormone-binding globulin (SHBG) concentrations [6].

PCOS has usually managed with lifestyle modification and drug therapy with different combinations of hormonal preparations and insulin sensitising agents. Antiandrogens such as cyproterone acetate and drospirenone combined with oestrogen (to regularise the menstrual cycle) are the preferred hormonal treatments. Combined oral contraceptive pills containing progestins with less andro- 
genic properties are an alternative option. Previous studies on the effects of currently available treatments for PCOS on glucose and lipid homeostasis and androgenic hormone profile have shown conflicting results [7] [8].

The objective of this study was to determine the effectiveness of ethinylestradiol/cyproterone (EE/CPA) and ethinylestradiol/desogestrel (EE/DES) alone and in combination with low-dose metformin on glucose and lipid homeostasis and androgenic hormone profile in hirsute women with PCOS.

\section{Methods}

\subsection{Study Population}

A total of 157 patients attending medical and gynaecology clinics at Teaching Hospitals Kandy and Peradeniya, Sri Lanka were assessed for eligibility and 107 were recruited. The inclusion criteria were subjects aged 18 to 40 years with PCOS diagnosed according to Rotterdam Consensus Conference Criteria 2003 with a modified Ferriman-Gallway hirsutism score of 8 or more. Patients with secondary causes of hyperandrogenism, with contraindications to the use of trial drugs, taking any form of hormonal contraceptives during the last 3 months and seeking fertility were excluded. Ethical approval was obtained from the Institutional Ethics Review Committee of the Faculty of Medicine, University of Peradeniya, Sri Lanka (protocol 2013/EC/52). The trial was registered at the Sri Lanka Clinical Trials Registry (https://slctr.lk/trials/slctr-2015-007) and the registration number was SLCTR/2015/007.

Written informed consent was obtained from all subjects and the study was conducted in accordance with the Declaration of Helsinki. Patient recruitment commenced in April 1, 2015 and each patient was followed up for a period of 12 months.

\subsection{Sample Size}

Based on previous studies, the sample size was calculated using the formula:

$$
N=\frac{2 \sigma^{2}}{\left(\mu_{1}-\mu_{2}\right)^{2}} f(\alpha, \beta)
$$

where $\sigma$ is the standard deviation and $\mu$ is the sample mean. The value of $\alpha$ was taken at $95 \%$ confidence level and $\beta$ at $80 \%$ confidence level.

According to the calculation, a sample size of 100 patients in each arm was planned. During the trial, an interim analysis was done by an independent statistician to ascertain the adequacy of the sample because of logistic reasons using the same formula as above. Accordingly, a sample size of 25 patients in each arm was considered adequate and patient recruitment was stopped when that target was reached.

\subsection{Randomization and Masking}

Simple randomization to four study arms was done by a computer-generated 
random number table. Treatment was started according to the assigned arm (A, $\mathrm{B}, \mathrm{C}$ or D). All logistics were overseen by an administrator who was not involved in the rest of the study.

Subjects of all four arms were given three kinds of tablets using appropriate placebos. All the investigators, statistician and patients were blinded to the treatment except the pharmacist who dispensed the drugs.

\subsection{Treatment Allocation}

Treatment allocation for the four arms is shown in Table 1. Treatments used in the study were EE/CPA (Diane-35, Schering AG, Berlin, Germany), EE/DES (Fermion, Infar (India) Ltd., India), metformin (State Pharmaceuticals Manufacturing Corporation, Sri Lanka) and three placebo pills (State Pharmaceuticals Manufacturing Corporation, Sri Lanka) equal to the above three drugs.

Metformin or placebo was commenced on the day of recruitment and continued daily. The other two tablets or placebos were started on the first day of the menstruation and continued for 21 days and resumed after a 7-day interval. Likewise, treatment was continued for 12 months and subjects were assessed according to the protocol detailed below.

\subsection{Outcome Measures}

Body mass index (BMI), fasting plasma glucose (FPG), area under the curve (AUC) of the oral glucose tolerance test (OGTT), fasting serum insulin, HOMA- $\beta$ and HOMA-IR, serum leptin, fasting lipid levels, sex hormone-binding globulin (SHBG), serum total testosterone level and free androgen index (FAI) were determined at the beginning and end of 12 months.

\subsubsection{Body Mass Index}

BMI was calculated using the weight (in kilograms) measured by a digital

Table 1. Medications used in each treatment arm.

\begin{tabular}{l} 
Arm \\
\hline A \\
1) Cyproterone acetate (2 mg) and of Ethinylestradiol (35 microg) daily \\
2) Placebo pill equal to metformin daily \\
3) Placebo pill equal to desogestrel $0.15 \mathrm{mg} /$ Ethinylestradiol (20 microg) daily \\
1) Desogestrel $0.15 \mathrm{mg} /$ Ethinylestradiol (20 microg) daily \\
2) Placebo pill equal to metformin daily \\
3) Placebo pill equal to Cyproterone acetate (2 mg) and of Ethinylestradiol \\
(35 microg) daily \\
1) Metformin $500 \mathrm{mg}$ daily \\
2) Cyproterone acetate (2 mg) and of Ethinylestradiol (35 microg) daily \\
3) placebo pill equal to desogestrel 0.15 mg/Ethinylestradiol (20 microg) daily \\
1) Metformin $500 \mathrm{mg}$ daily \\
2) Desogestrel $0.15 \mathrm{mg} /$ Ethinylestradiol (20 microg) daily \\
3) Placebo pill equal to Cyproterone acetate (2 mg) and of Ethinylestradiol \\
(35 microg) pill daily
\end{tabular}


weighing scale and height (in meters) measured by a standard height measuring scale.

\subsubsection{Collection and Analysis of Blood Samples}

The tests were carried out in the laboratories of the Department of Biochemistry, Department of Medicine, Department of Pharmacology, and Nuclear Medicine Unit, Faculty of Medicine, University of Peradeniya.

The tests were performed on venous blood samples drawn after 12 hours of fasting followed by OGTT.

\subsubsection{Oral Glucose Tolerance Test}

Oral glucose tolerance test was done according to WHO guidelines [9]. Samples were collected and centrifuged in a bench top centrifuge (Humax 4k Germany) at $3000 \mathrm{rpm}$ for $10 \mathrm{~min}$ to obtain plasma. Plasma was analysed with DR-7000D Semi-Automatic Chemistry Analyser (DIRUI, Changchun, China) using glucose oxidase method to measure plasma glucose level. Plasma glucose levels at fasting state, at one hour and two hours after glucose load, were measured. The AUC of the OGTT was calculated by the trapezoidal method

\subsubsection{Serum Insulin, Leptin and SHBG Measurements}

Fasting serum insulin, leptin and SHBG were measured using commercially available ELISA kits (Calbiotech Inc. Canada).

\subsubsection{Homeostasis Model Assessment (HOMA)}

The HOMA calculators that were used to estimate these values are as follows:

$$
\begin{gathered}
\text { HOMA }-\mathrm{IR}=(\mathrm{FPI} \times \mathrm{FPG}) / 22.5 \\
\mathrm{HOMA}-\beta=(20 \times \mathrm{FPI}) /(\mathrm{FPG}-3.5)
\end{gathered}
$$

(FPI is fasting plasma insulin and FPG is fasting plasma glucose).

\subsubsection{Measurement of Fasting Lipids}

Plasma triglyceride concentration (TAG) was determined using an enzymatic colorimetric test (Triglycerides liquicolor mono, Human Diagnostics, Wiesbaden, Germany). Serum total cholesterol concentrations (TC) were determined by using an enzymatic colorimetric test (Triglycerides liquicolor, Human Diagnostics, Wiesbaden, Germany). HDL cholesterol (HDL-C) was also measured by an enzymatic method after heparin and calcium precipitation (HDL liquicolor, Human Diagnostics, Wiesbaden, Germany). LDL cholesterol (LDL-C ) in mg/dl was calculated with the Friedewald equation $($ LDL cholesterol) $=$ (total cholesterol) - (HDL cholesterol) - (triglycerides)/5).

\subsubsection{Testosterone Measurement}

Testosterone levels were determined using the testosterone radioimmunoassay kit (TESTO-CT2 assay; Cisbio Bioassays, Codolet, France).

\subsubsection{Free Androgen Index}

Free androgen index was calculated by the following formula. 


$$
\text { Free androgen index }=\frac{\text { Total testosterone }}{\text { SHBG }} \times 100
$$

\subsection{Statistical Analysis}

Statistical analysis was done with SPSS software version 22. Per-protocol analysis was done to find out the baseline group differences between completed subjects, within-group differences and group differences from baseline to 12 months.

Two-way mixed ANOVA model for repeated measures was used during the analysis. Additionally, one way ANOVA and categorical data analytical methods were used wherever appropriate.

Before applying two way mixed ANOVA model, the significant outliers in each variable were excluded. Leven's and Mauchly's tests were used to ensure the homogeneity and spherecity of the outcome variables respectively. Where spherecity is not assured, Greenhouse Geisser or Huynh-Feldt test was used to calculate the $\mathrm{P}$ values. Statistical significance was defined as $\mathrm{P}<0.05$.

\section{Results}

Figure 1 shows the summary of the patient recruitment and follow-up. In group

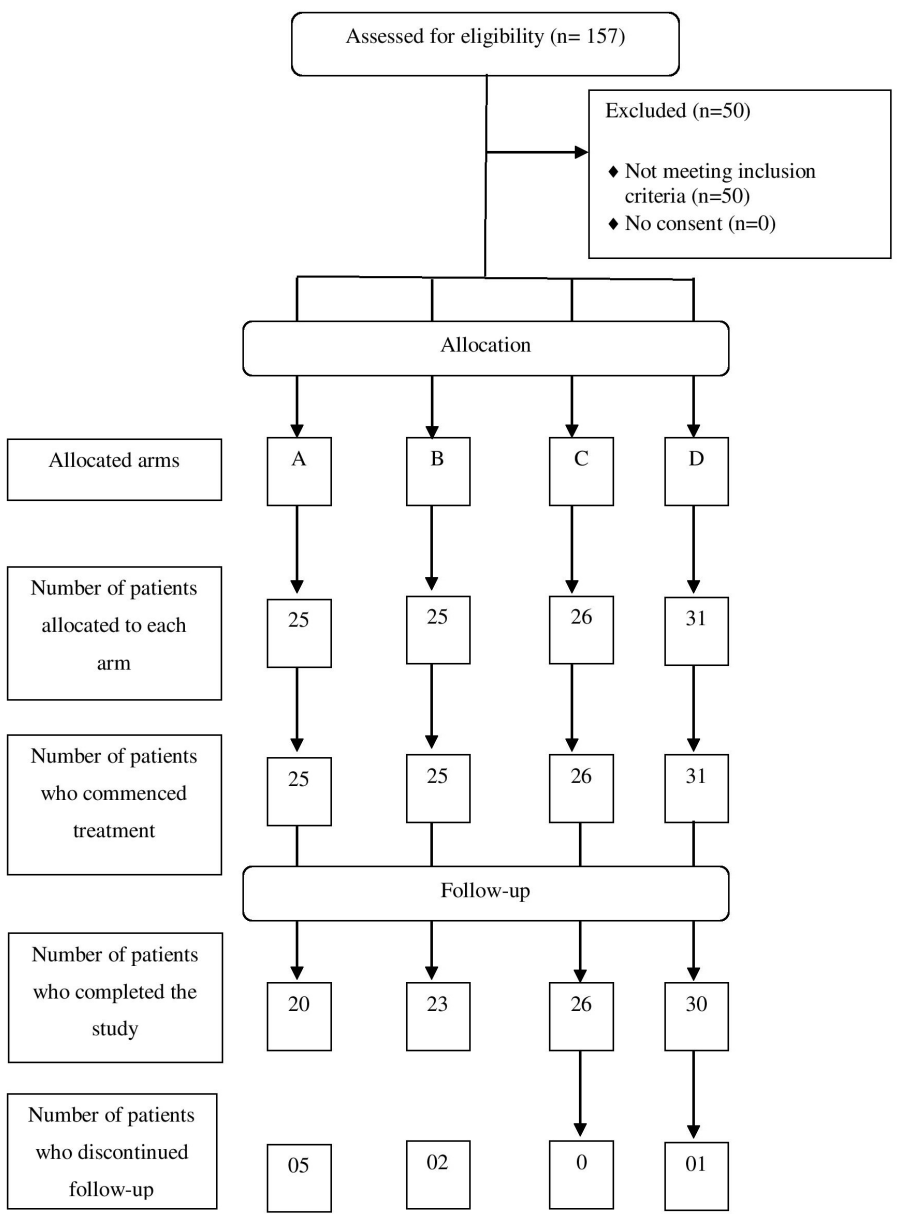

Figure 1. Summary of the patient recruitment and follow-up. 
A, there were 5 dropouts. All five patients had treatment-related adverse effects which include migraine-type headache, joint stiffness, severe breast tenderness, vomiting, and faintness. In group B, there were two dropouts. One patient was diagnosed of papillary carcinoma of the thyroid and other wanted to conceive. In group $\mathrm{C}$, there were no dropouts. In group $\mathrm{D}$, there was one dropout due to recurrent faintness.

Table 2 shows the baseline variables of the four treatment arms. None of the baseline variables other than the age in arm $\mathrm{D}$ showed a statistically significant difference.

None of the outcome measures showed a significant difference between the treatment arms at the end of 12 months. However, there were statistically significant changes seen within the treatment arms in certain outcome measures.

Table 3 summaries the glucose and androgenic hormone profile changes of each treatment arm, while Table 4 shows lipid profile changes. There was a statistically significant reduction in BMI within treatment arm A, HOMA- $\beta$ within arm $B$, leptin level within arm $C$ and TC/HDL ratio in arm $D$ at the end of 12 months. A statistically significant rise in total cholesterol and LDL-C were seen in arms B and C.

Three patients had FPG values in the diabetic range at the end of 12 months. However, the number of patients with normal fasting glucose at recruitment later developing impaired fasting glucose or diabetes did not show a statistically significant difference $\left(\mathrm{X}^{2}=0.8449 ; \mathrm{df}=3 ; \mathrm{P}=0.8387\right)$. Statistically significant changes in outcomes observed at 12 months are summarized in Table 5 and Table 6.

\section{Discussion}

The main findings in our study were reduction of HOMA- $\beta$ in EE/DES arm, reduction of serum leptin in EE/CPA plus metformin arm, reduction of $\mathrm{CHO} / \mathrm{HDL}$ ratio in EE/DES plus metformin arm and an increase in TC and LDL-C in both EE/DES arm and EE/CPA plus metformin arm.

The reduction of $\mathrm{BMI}$ within the EE/CPA group is unlikely to be due to the drug because the EE/CPA plus metformin group did not show the similar change. Impaired beta-cell function with desogrestrel indicated by the reduced HOMA- $\beta$ is a notable finding in our study. Previous studies on oral contraceptives containing cyproterone, desogestrel and drospirenone have failed to demonstrate changes in biochemical parameters of insulin resistance [10] [11] [12]. This is in keeping with our findings as well.

The effects of COCPs on lipid and carbohydrate metabolism depend on the dose of the estrogen and the dose, type and androgenicity of the progestin [13]. Studies on the effects of DES on glucose homeostasis have shown decreased insulin sensitivity in some studies and no effect on fasting insulin and fasting glucose, reduced postprandial glucose and increased insulin sensitivity in others [12] [14] [15]. 
Table 2. Baseline values of variables of patients who completed the follow-up.

\begin{tabular}{|c|c|c|c|c|c|c|c|c|c|}
\hline \multirow[b]{3}{*}{ Variables } & \multicolumn{2}{|r|}{ A } & \multicolumn{2}{|r|}{ B } & \multicolumn{2}{|r|}{$\mathrm{C}$} & \multicolumn{2}{|r|}{$\mathrm{D}$} & \multirow[b]{3}{*}{$P$ value } \\
\hline & \multicolumn{2}{|c|}{ Baseline } & \multicolumn{2}{|c|}{ Baseline } & \multicolumn{2}{|c|}{ Baseline } & \multicolumn{2}{|r|}{ Baseline } & \\
\hline & $\mathbf{N}$ & Mean \pm SD & $\mathrm{N}$ & Mean \pm SD & $\mathbf{N}$ & Mean \pm SD & $\mathbf{N}$ & Mean \pm SD & \\
\hline Age & 20 & $23.35 \pm 5.10$ & 23 & $22.39 \pm 6.45$ & 26 & $24.81 \pm 6.24$ & 30 & $27.90 \pm 6.89$ & $\mathrm{P}=0.013$ \\
\hline \multicolumn{10}{|c|}{ Marital status } \\
\hline Married & & 5 & & 5 & & 8 & & 8 & \\
\hline Unmarried & & 15 & & 18 & & 18 & & 22 & \\
\hline BMI $\left(\mathrm{kg} / \mathrm{m}^{2}\right)$ & 20 & $28.27 \pm 6.94$ & 23 & $26.74 \pm 4.88$ & 26 & $27.93 \pm 4.89$ & 29 & $27.20 \pm 4.28$ & $\mathrm{P}>0.05$ \\
\hline Waist /Hip ratio & 20 & $0.84 \pm 0.09$ & 23 & $0.83 \pm 0.09$ & 26 & $0.84 \pm 0.06$ & 29 & $0.83 \pm 0.12$ & $\mathrm{P}>0.05$ \\
\hline $\begin{array}{l}\text { Ferriman-Gallwey } \\
\text { Score }\end{array}$ & 20 & $20.95 \pm 5.50$ & 23 & $20.00 \pm 6.67$ & 26 & $21.08 \pm 5.24$ & 29 & $18.38 \pm 5.53$ & $\mathrm{P}>0.05$ \\
\hline $\begin{array}{l}\text { Systolic blood } \\
\text { pressure }(\mathrm{mm} \mathrm{Hg})\end{array}$ & 20 & $118.80 \pm 17.03$ & 23 & $117.87 \pm 12.16$ & 25 & $116.64 \pm 11.38$ & 29 & $120.66 \pm 13.44$ & $\mathrm{P}>0.05$ \\
\hline $\begin{array}{l}\text { Diastolic blood } \\
\text { pressure (mm Hg) }\end{array}$ & 20 & $78.75 \pm 13.60$ & 23 & $76.43 \pm 8.86$ & 25 & $77.44 \pm 10.72$ & 29 & $80.10 \pm 9.07$ & $\mathrm{P}>0.05$ \\
\hline \multicolumn{10}{|c|}{ Hormones } \\
\hline $\begin{array}{l}\text { Testosterone } \\
\text { (ng/dL) }\end{array}$ & 20 & $2.51 \pm 2.71$ & 23 & $19.60 \pm 83.82$ & 25 & $2.79 \pm 1.82$ & 30 & $2.84 \pm 2.50$ & $\mathrm{P}>0.05$ \\
\hline SHBG (nmol/L) & 20 & $103.24 \pm 72.79$ & 22 & $82.07 \pm 69.78$ & 26 & $87.06 \pm 84.11$ & 30 & $88.87 \pm 70.87$ & $\mathrm{P}>0.05$ \\
\hline FAI & 20 & $4.99 \pm 8.86$ & 22 & $4.31 \pm 4.82$ & 25 & $6.29 \pm 7.23$ & 28 & $4.08 \pm 3.41$ & $\mathrm{P}>0.05$ \\
\hline HOMA-IR & 20 & $14.02 \pm 22.06$ & 23 & $10.11 \pm 27.57$ & 26 & $17.41 \pm 40.32$ & 29 & $5.39 \pm 11.39$ & $\mathrm{P}>0.05$ \\
\hline HOMA-B & 20 & $86.33 \pm 234.26$ & 22 & $257.63 \pm 569.49$ & 26 & $52.99 \pm 132.01$ & 29 & $79.46 \pm 238.73$ & $\mathrm{P}>0.05$ \\
\hline Leptin & 20 & $23.79 \pm 25.62$ & 22 & $21.32 \pm 16.32$ & 26 & $23.58 \pm 17.34$ & 28 & $27.70 \pm 26.38$ & $\mathrm{P}>0.05$ \\
\hline \multicolumn{10}{|c|}{ Lipid parameters } \\
\hline $\begin{array}{l}\text { Cholesterol } \\
(\mathrm{mg} / \mathrm{dL})\end{array}$ & 20 & $200.45 \pm 37.60$ & 23 & $178.72 \pm 40.04$ & 26 & $198.58 \pm 39.80$ & 30 & $189.91 \pm 34.99$ & $\mathrm{P}>0.05$ \\
\hline HDL (mg/dL) & 20 & $47.20 \pm 11.15$ & 23 & $42.43 \pm 8.86$ & 26 & $42.92 \pm 7.32$ & 30 & $44.31 \pm 24.58$ & $\mathrm{P}>0.05$ \\
\hline $\mathrm{LDL}(\mathrm{mg} / \mathrm{dL})$ & 20 & $130.85 \pm 31.92$ & 23 & $116.34 \pm 29.03$ & 26 & $129.80 \pm 35.04$ & 30 & $119.17 \pm 33.22$ & $\mathrm{P}>0.05$ \\
\hline $\begin{array}{l}\text { Triglycerides } \\
(\mathrm{mg} / \mathrm{dL})\end{array}$ & 20 & $111.20 \pm 40.19$ & 23 & $119.57 \pm 71.73$ & 26 & $129.27 \pm 66.01$ & 30 & $137.87 \pm 78.63$ & $\mathrm{P}>0.05$ \\
\hline $\begin{array}{l}\text { Cholesterol/HDL } \\
\text { Ratio }\end{array}$ & 20 & $4.37 \pm 0.95$ & 23 & $4.56 \pm 1.15$ & 26 & $4.72 \pm 1.10$ & 29 & $4.84 \pm 1.24$ & $\mathrm{P}>0.05$ \\
\hline \multicolumn{10}{|c|}{ Glycemic parameters from OGTT } \\
\hline $\begin{array}{l}\text { Fasting glucose } \\
(\mathrm{mg} / \mathrm{dL})\end{array}$ & 20 & $83.80 \pm 17.61$ & 23 & $82.00 \pm 15.42$ & 26 & $87.23 \pm 14.33$ & 30 & $86.37 \pm 18.19$ & $\mathrm{P}>0.05$ \\
\hline $\begin{array}{l}\text { Fasting insulin } \\
(\mu \mathrm{U} / \mathrm{mL})\end{array}$ & 20 & $5.77 \pm 5.77$ & 23 & $9.33 \pm 15.22$ & 26 & $8.84 \pm 14.76$ & 30 & $6.81 \pm 13.93$ & $\mathrm{P}>0.05$ \\
\hline
\end{tabular}

Note: SHBG, Sex hormone binding globulin. FAI, Free androgen index. BMI, Body mass index. HOMA-IR, homeostasis model assessment-estimated insulin resistance. HOMA- $\beta$, homeostasis model assessment of $\beta$-cell function. HDL, High density lipoprotein. LDL, Low density lipoprotein.

The results of studies on the effect of cyproterone acetate on carbohydrate metabolism are also conflicting. Insulin sensitivity was increased or unchanged in non-obese women with PCOS and worsened in obese patients [16]. Worsening 
Table 3. Glucose and androgenic hormone profile.

\begin{tabular}{|c|c|c|c|c|c|c|c|c|c|c|c|}
\hline & & $\begin{array}{c}\text { BMI } \\
\text { Mean } \pm \\
\text { SD }\end{array}$ & $\begin{array}{l}\text { Fasting } \\
\text { glucose } \\
\text { (mg/dl) }\end{array}$ & $\begin{array}{c}\text { Fasting } \\
\text { Insulin } \\
(\mathrm{IU} /)\end{array}$ & HOMA $\beta$ & HOMA IR & AUC & Leptin & SHBG & Testosterone & FAI \\
\hline \multirow{3}{*}{ Arm A } & 0 month & $28.3 \pm 6.9$ & $83.8 \pm 17.6$ & $5.8 \pm 5.8$ & $86.3 \pm 234.3$ & $14.0 \pm 22.1$ & $\begin{array}{c}209.8 \pm \\
34.8\end{array}$ & $\begin{array}{c}23.79 \pm \\
25.62\end{array}$ & $\begin{array}{c}107.41 \pm \\
72.29\end{array}$ & $2.51 \pm 2.71$ & $4.99 \pm 8.86$ \\
\hline & 12 months & $26.9 \pm 6.7$ & $95.1 \pm 32.0$ & $4.3 \pm 6.5$ & $44.3 \pm 101.1$ & $3.8 \pm 4.2$ & $\begin{array}{c}230.4 \pm \\
29.9\end{array}$ & $\begin{array}{c}24.86 \pm \\
22.63\end{array}$ & $\begin{array}{c}148.18 \pm \\
95.14\end{array}$ & $2.85 \pm 2.92$ & $2.39 \pm 2.54$ \\
\hline & $P$ value & 0.009 & 0.9 & 0.659 & 0.565 & 0.196 & 1 & 0.789 & 0.066 & 0.97 & 0.104 \\
\hline \multirow{3}{*}{ Arm B } & 0 month & $26.7 \pm 4.9$ & $82 \pm 15.4$ & $9.3 \pm 15.2$ & $\begin{array}{c}257.6 \pm \\
559.4\end{array}$ & $10.1 \pm 27.6$ & $\begin{array}{c}216.7 \pm \\
39.5\end{array}$ & $\begin{array}{c}21.32 \pm \\
16.32\end{array}$ & $\begin{array}{c}82.80 \pm \\
71.42\end{array}$ & $19.60 \pm 83.82$ & $4.31 \pm 4.82$ \\
\hline & 12 months & $26.1 \pm 4.4$ & $95.1 \pm 23.7$ & $8.3 \pm 15.0$ & $91.4 \pm 160.7$ & $4.3 \pm 4.8$ & $\begin{array}{c}232.2 \pm \\
28.8\end{array}$ & $\begin{array}{c}20.89 \pm \\
19.38\end{array}$ & $\begin{array}{c}110.49 \pm \\
76.76\end{array}$ & $3.68 \pm 2.84$ & $6.20 \pm 10.49$ \\
\hline & $P$ value & 0.775 & 0.9 & 0.732 & 0.019 & 0.427 & 1 & 0.91 & 0.246 & 0.063 & 0.213 \\
\hline \multirow{3}{*}{ Arm C } & 0 month & $27.9 \pm 4.9$ & $87.2 \pm 22.5$ & $8.8 \pm 14.8$ & $53.0 \pm 132.6$ & $17.4 \pm 40.3$ & $\begin{array}{c}230.7 \pm \\
80.3\end{array}$ & $\begin{array}{c}23.58 \pm \\
17.34\end{array}$ & $\begin{array}{c}88.80 \pm \\
85.36\end{array}$ & $2.79 \pm 1.82$ & $6.29 \pm 7.23$ \\
\hline & 12 months & $27.1 \pm 4.6$ & $92.7 \pm 22.8$ & $5.5 \pm 11.8$ & $35.8 \pm 52.4$ & $11.9 \pm 39.7$ & $\begin{array}{c}224.7 \pm \\
25.1\end{array}$ & $\begin{array}{c}16.44 \pm \\
9.74\end{array}$ & $\begin{array}{c}93.57 \pm \\
82.57\end{array}$ & $2.49 \pm 1.64$ & $4.98 \pm 5.79$ \\
\hline & $P$ value & 0.224 & 0.407 & 0.264 & 0.788 & 0.428 & 0.737 & 0.044 & 0.921 & 0.971 & 0.357 \\
\hline \multirow{3}{*}{ Arm D } & 0 month & $27.2 \pm 4.3$ & $86.4 \pm 28.5$ & $6.8 \pm 13.9$ & $79.5 \pm 239.0$ & $5.4 \pm 11.4$ & $\begin{array}{c}213.4 \pm \\
35.0\end{array}$ & $\begin{array}{c}27.70 \pm \\
26.38\end{array}$ & $\begin{array}{c}86.06 \pm \\
70.40\end{array}$ & $2.84 \pm 2.50$ & $4.08 \pm 3.41$ \\
\hline & 12 months & $26.8 \pm 3.6$ & $98.4 \pm 30.9$ & $7.6 \pm 16.4$ & $\begin{array}{c}128.8 \pm \\
116.5\end{array}$ & $7.3 \pm 23.9$ & $\begin{array}{c}223.6 \pm \\
37.3\end{array}$ & $\begin{array}{c}21.58 \pm \\
21.57\end{array}$ & $\begin{array}{c}101.78 \pm \\
85.09\end{array}$ & $3.03 \pm 2.60$ & $4.09 \pm 3.93$ \\
\hline & $P$ value & 1.000 & 0.019 & 0.777 & 0.416 & 0.768 & 0.737 & 0.073 & 0.511 & 0.98 & 0.996 \\
\hline
\end{tabular}

Note: BMI, Body mass index. HOMA- $\beta$, homeostasis model assessment of $\beta$-cell function. HOMA-IR, homeostasis model assessment-estimated insulin resistance. AUC, Area under the curve of oral glucose tolerance test. SHBG, Sex hormone binding globulin.

Table 4. Lipid profiles.

\begin{tabular}{|c|c|c|c|c|c|c|}
\hline & & $\begin{array}{c}\text { Total } \\
\text { Cholesterol }\end{array}$ & Triglyceride & HDL & LDL & Ratio \\
\hline \multirow{4}{*}{ Arm A } & 0 month & $200.4 \pm 37.6$ & $111.2 \pm 40.1$ & $47.2 \pm 11.1$ & $130.8 \pm 31.9$ & $4.3 \pm 0.9$ \\
\hline & 12 months & $215.7 \pm 46.4$ & $121.2 \pm 82.5$ & $50.2 \pm 1.6$ & $50.2 \pm 5.8$ & $4.3 \pm 0.8$ \\
\hline & Mean changes from baseline (\%) & -7.63 & -8.95 & -6.36 & -5.67 & 1.08 \\
\hline & $P$ value & 0.062 & 0.368 & 0.487 & 0.193 & 0.827 \\
\hline \multirow{4}{*}{ Arm B } & 0 month & $178.7 \pm 40.0$ & $119.6 \pm 71.7$ & $42.4 \pm 8.9$ & $116.3 \pm 29.0$ & $4.6 \pm 1.2$ \\
\hline & 12 months & $205.0 \pm 36.5$ & $116.3 \pm 45.0$ & $49.9 \pm 10.4$ & $127.4 \pm 36.0$ & $4.2 \pm 0.9$ \\
\hline & Mean changes from baseline (\%) & -14.68 & 2.73 & -17.52 & -9.46 & 7.22 \\
\hline & $P$ value & 0.001 & 0.751 & 0.067 & 0.040 & 0.104 \\
\hline \multirow{4}{*}{ Arm C } & 0 month & $198.6 \pm 39.8$ & $129.3 \pm 66.0$ & $42.9 \pm 7.3$ & $129.8 \pm 35.0$ & $4.7 \pm 1.1$ \\
\hline & 12 months & $217.3 \pm 41.6$ & $141.0 \pm 61.6$ & $49.1 \pm 9.9$ & $139.6 \pm 35.1$ & $4.5 \pm 0.9$ \\
\hline & Mean changes from baseline (\%) & -9.45 & -9.1 & -14.43 & -7.56 & 4.93 \\
\hline & P value & 0.010 & 0.226 & 0.104 & 0.051 & 0.219 \\
\hline \multirow{4}{*}{ Arm D } & 0 month & $189.9 \pm 35.0$ & $137.9 \pm 78.6$ & $44.3 \pm 24.6$ & $119.2 \pm 33.2$ & $4.8 \pm 1.2$ \\
\hline & 12 months & $198.5 \pm 41.8$ & $143.2 \pm 66.2$ & $44.7 \pm 11.2$ & $121.0 \pm 36.5$ & $4.4 \pm 0.8$ \\
\hline & Mean changes from baseline (\%) & -4.5 & -3.84 & -0.87 & -1.57 & 8.32 \\
\hline & $P$ value & 0.200 & 0.557 & 0.913 & 0.686 & 0.026 \\
\hline
\end{tabular}


Table 5. Variables which have statistically significantly decreased at the end of 12 months.

\begin{tabular}{cc}
\hline Arm & Variable \\
\hline A & BMI \\
B & HOMA- $\beta$ index \\
C & Serum leptin, \\
D & Total cholesterol/HDL-C ratio \\
\hline
\end{tabular}

Note: BMI, Body mass index. HOMA- $\beta$, Homeostasis model assessment of $\beta$-cell function.

Table 6. Variables which have statistically significantly increased at the end of 12 months.

\begin{tabular}{cc}
\hline Arm & Variable \\
\hline B & Total cholesterol, LDL-cholesterol \\
C & Total cholesterol, LDL cholesterol \\
\hline
\end{tabular}

Note: LDL, Low density lipoprotein.

of glucose homeostasis has been noted in obese women with PCOS with higher doses of cyproterone acetate (12.5 mg/day) in another study [17]. In the present study, we employed a dose of $2 \mathrm{mg}$ of cyproterone acetate with oestrogen and there was no significant change in insulin sensitivity. We did not analyse results according to body weight and it is a shortcoming in our study.

The effects of metformin therapy on insulin sensitivity in PCOS patients also have conflicting evidence. Some investigators assessing insulin sensitivity have shown a significant improvement during metformin treatment [18] [19] [20] whereas others have failed to confirm it [21] [22]. Adding metformin to either of hormonal therapies in this study has not changed the outcome probably due to the low dose of metformin.

$\mathrm{EE} / \mathrm{DES}, \mathrm{EE} / \mathrm{CPA}$ and metformin have been shown to reduce serum testosterone and increase SHBG in women with PCOS [23] [24]. Adding metformin (500 mg three times per day) to CPA improves serum androgenic hormone profile in non-obese women with PCOS [25]. Metformin (500 mg three times per day) has been shown to reduce the testosterone level after 6 months of therapy [26]. It is hypothesised that reduction of weight with metformin may increase the circulating level of SHBG [21]. However, the failure of metformin to influence circulating SHBG concentration has also been reported previously [27]. In our study, we did not find a significant change of serum testosterone, SHBG and FAI in the four study arms.

Serum leptin was significantly reduced only in treatment arm C (EE/CPA plus metformin). Serum leptin levels highly correlate with the body fat content and fall in response to weight loss [28].

In arm $\mathrm{C}$, there was no significant change of BMI although the leptin level came down. In arm A, there was a significant reduction of BMI but leptin level remained unchanged. The change of leptin did not clearly correlate with BMI in this study, perhaps because of the small sample size.

There are conflicting findings about serum leptin levels in PCOS. One study 
found no difference in serum leptin level between normal and PCOS subjects [29]. Another study showed that PCOS patients have leptin levels higher than the expected for their BMI, free testosterone and insulin sensitivity [4]. Metformin has been shown to decrease serum leptin level in PCOS [30].

Oestrogen favourably changes the lipid metabolism by increasing HDL-C and decreasing LDL-C [31]. Desogestrel elevates serum HDL-C more than second generation COCPs [14]. LDLC has been shown to remain unchanged with desogestrel [12] but it increases TC and TAG [12]. However, a study conducted on obese women with PCOS showed that desogestrel-containing OCP increases the LDL-C as well [15]. On the other hand, some studies have not observed changes in LDL-C or HDL-C levels [32].

Cyproterone acetate-containing COCPs reduce serum HDL-C and increase TC, LDL-C and TAG concentrations in both non-obese and obese subjects [33]. But some studies show a rise in HDL-C [7] [34]. Some do not show any change in LDL-C or HDL-C. Therefore, the effects of EE/DES and EE/CPA on lipids in PCOS women are not yet well established.

In diabetic patients, metformin has a beneficial effect on lipid levels due to reduced concentrations of plasma TAG and TC and LDL-C, and increased HDL-C and HDL: LDL cholesterol ratio [35]. In PCOS, metformin mainly increases serum HDL-C concentrations [20]. But some studies have shown negligible or no effect of metformin on lipids in PCOS [36]. These effects may change according to the BMI, duration of the study and dose of metformin.

\section{Conclusion}

This study has shown that treatment of hirsute women with PCOS with desogestrel is associated with reduced beta-cell function. Both desogrestrel and cyprpterone have favorable as well as unfavorable effects on serum lipids. Both hormones did not have a significant effect on serum androgen hormone profile. These outcomes may have been different with a longer duration of the treatment and a higher dose of metformin.

\section{Conflicts of Interest}

The authors declare no conflicts of interest regarding the publication of this paper.

\section{References}

[1] Hardiman, P., Pillay, O.C. and Atiomo, W. (2003) Polycystic Ovary Syndrome and Endometrial Carcinoma. The Lancet, 361, 1810-1812. https://doi.org/10.1016/S0140-6736(03)13409-5

[2] Messer, C., Boston, R., Leroith, D., Geer, E., Miller, J.D., Messer, M. and Futterweit, W. (2012) Pancreatic Beta-Cell Dysfunction in Polycystic Ovary Syndrome: The Role of Metformin. Endocrine Practice, 18, 685-693. https://doi.org/10.4158/EP11375.OR

[3] Wallace, T.M., Levy, J.C. and Matthews, D.R. (2004) Use and Abuse of HOMA 
Modeling. Diabetes Care, 27, 1487-1495. https://doi.org/10.2337/diacare.27.6.1487

[4] Brzechffa, P.R., Jakimiuk, A.J., Agarwal, S.K., Weitsman, S.R., Buyalos, R.P. and Magof-fin, D.A. (1996) Serum Immunoreactive Leptin Concentrations in Women with Polycystic Ovary Syndrome. The Journal of Clinical Endocrinology \& Metabolism, 81, 4166-4169. https://doi.org/10.1210/jcem.81.11.8923878

[5] Moll, G.W. and Rosenfield, R.L. (1979) Testosterone Binding and Free Plasma Androgen Concentrations under Physiological Conditons: Chararacterization by Flow Dialysis Technique. The Journal of Clinical Endocrinology \& Metabolism, 49, 730-736. https://doi.org/10.1210/jcem-49-5-730

[6] Miller, K.K., Rosner, W., Lee, H., Hier, J., Sesmilo, G., Schoenfeld, D., Neubauer, G. and Klibanski, A. (2004) Measurement of Free Testosterone in Normal Women and Women with Androgen Deficiency: Comparison of Methods. The Journal of Clinical Endocrinology \& Metabolism, 89, 525-533.

https://doi.org/10.1210/jc.2003-030680

[7] Falsetti, L. and Pasinetti, E. (1995) Effects of Long-Term Administration of an Oral Contraceptive Containing Ethinylestradiol and Cyproterone Acetate on Lipid Metabolism in Women with Polycystic Ovary Syndrome. Acta Obstetricia et Gynecologica Scandinavica, 74, 56-60. https://doi.org/10.3109/00016349509009945

[8] Legro, R.S., Kunselman, A.R., Dodson, W.C., Dunaif, A. (1999) Prevalence and Predictors of Risk for Type 2 Diabetes Mellitus and Impaired Glucose Tolerance in Polycystic Ovary Syndrome: A Prospective, Controlled Study in 254 Affected Women. The Journal of Clinical Endocrinology \& Metabolism, 84, 165-169. https://doi.org/10.1210/jcem.84.1.5393

[9] World Health Organization (1999) Definition, Diagnosis and Classification of Diabetes Mellitus and Its Complications: Report of a WHO Consultation Part 1: Diagnosis and Classification of Diabetes Mellitus. 2nd Edition, World Health Organization, Geneva.

[10] Bhattacharya, S.M. and Jha, A. (2012) Comparative Study of the Therapeutic Effects of Oral Contraceptive Pills Containing Desogestrel, Cyproterone Acetate, and Drospirenone in Patients with Polycystic Ovary Syndrome. Fertility and Sterility, 98, 1053-1059. https://doi.org/10.1016/j.fertnstert.2012.06.035

[11] Gaspard, U., Scheen, A., Endrikat, J., Buicu, C., Lefebvre, P., Gerlinger, C. and Hei-thecker, R. (2003) A Randomized Study over 13 Cycles to Assess the Influence of Oral Contraceptives Containing Ethinylestradiol Combined with Drospirenone or Desogestrel on Carbohydrate Metabolism. Contraception, 67, 423-429. https://doi.org/10.1016/S0010-7824(02)00537-1

[12] Klipping, C. and Marr, J. (2005) Effects of Two Combined Oral Contraceptives Containing Ethinyl Estradiol 20 Microg Combined with Either Drospirenone or Desogestrel on Lipids, Hemostatic Parameters and Carbohydrate Metabolism. Contraception, 71, 409-416. https://doi.org/10.1016/j.contraception.2004.12.005

[13] Sitruk-Ware, R. and Nath, A. (2011) Metabolic Effects of Contraceptive Steroids. Reviews in Endocrine and Metabolic Disorders, 12, 63-75.

https://doi.org/10.1007/s11154-011-9182-4

[14] Cagnacci, A., Ferrari, S., Tirelli, A., Zanin, R. and Volpe, A. (2009) Insulin Sensitivity and Lipid Metabolism with Oral Contraceptives Containing Chlormadinone Acetate or Desogestrel: A Randomized Trial. Contraception, 79, 111-116. https://doi.org/10.1016/j.contraception.2008.09.002

[15] Shahnazi, M., Farshbaf-Khalili, A., Pourzeinali-Beilankouh, S. and Sadrimehr, F. (2016) Effects of Second and Third Generation Oral Contraceptives on Lipid and 
Carbohydrate Metabolism in Overweight and Obese Women: A Randomized Triple-Blind Controlled Trial. Iranian Red Crescent Medical Journal, 18, e36982. https://doi.org/10.5812/ircmj.36982

[16] Morin-Papunen, L.C., Vauhkonen, I., Koivunen, R.M., Ruokonen, A., Martikainen, H.K. and Tapanainen, J.S. (2000) Endocrine and Metabolic Effects of Metformin versus Ethinyl Estradiol-Cyproterone Acetate in Obese Women with Polycystic Ovary Syndrome: A Randomized Study. The Journal of Clinical Endocrinology \& Metabolism, 85, 3161-3168. https://doi.org/10.1210/jc.85.9.3161

[17] Fruzzetti, F., Perini, D., Lazzarini, V., Parrini, D., Gambacciani, M. and Genazzani, A.R. (2010) Comparison of Effects of $3 \mathrm{mg}$ Drospirenone plus $20 \mu \mathrm{g}$ Ethinylestradiol Alone or Combined with Metformin or Cyproterone Acetate on Classic Metabolic Cardiovascular Risk Factors in Nonobese Women with Polycystic Ovary Syndrome. Fertility and Sterility, 94, 1793-1798.

https://doi.org/10.1016/j.fertnstert.2009.10.016

[18] Unluhizarci, K., Kelestimur, F., Sahin, Y. and Bayram, F. (1999) The Treatment of Insulin Resistance Does Not Improve Adrenal Cytochrome P450c17alpha Enzyme Dysregulation in Polycystic Ovary Syndrome. European Journal of Endocrinology, 140, 56-61. https://doi.org/10.1530/eje.0.1400056

[19] Diamanti-Kandarakis, E., Kouli, C., Tsianateli, T. and Bergiele, A. (1998) Therapeutic Effects of Metformin on Insulin Resistance and Hyperandrogenism in Polycystic Ovary Syndrome. European Journal of Endocrinology, 138, 269-274. https://doi.org/10.1530/eje.0.1380269

[20] Moghetti, P., Castello, R., Negri, C., Tosi, F., Perrone, F., Caputo, M., Zanolin, E. and Muggeo, M. (2000) Metformin Effects on Clinical Features, Endocrine and Metabolic Profiles, and Insulin Sensitivity in Polycystic Ovary Syndrome: A Randomized, Double-Blind, Placebo-Controlled 6-Month Trial, Followed by Open, Long-Term Clinical Evaluation. The Journal of Clinical Endocrinology \& Metabolism, 85, 139-146. https://doi.org/10.1210/jcem.85.1.6293

[21] Crave, J.C., Fimbel, S., Lejeune, H., Cugnardey, N., Dechaud, H. and Pugeat, M. (1995) Effects of Diet and Metformin Administration on Sex Hormone-Binding Globulin, Androgens, and Insulin in Hirsute and Obese Women. The Journal of Clinical Endocrinology \& Metabolism, 80, 2057-2062.

https://doi.org/10.1210/jcem.80.7.7608255

[22] Acbay, O. and Gundogdu, S. (1996) Can Metformin Reduce Insulin Resistance in Polycystic Ovary Syndrome? Fertility and Sterility, 65, 946-949.

https://doi.org/10.1016/S0015-0282(16)58266-1

[23] Cullberg, G., Hamberger, L., Mattsson, L.-Å., Mobacken, H. and Samsioe, G. (1985) Effects of a Low-Dose Desogestrel-Ethinylestradiol Combination on Hirsutism, Androgens and Sex Hormone Binding Globulin in Women with a Polycystic Ovary Syndrome. Acta Obstetricia et Gynecologica Scandinavica, 64, 195-202. https://doi.org/10.3109/00016348509155112

[24] Wu, J., Zhu, Y., Jiang, Y. and Cao, Y. (2008) Effects of Metformin and Ethinyl Estradiol-Cyproterone Acetate on Clinical, Endocrine and Metabolic Factors in Women with Polycystic Ovary Syndrome. Gynecological Endocrinology, 24, 392-398. https://doi.org/10.1080/09513590802217027

[25] Elter, K., Imir, G. and Durmusoglu, F. (2002) Clinical, Endocrine and Metabolic Effects of Metformin Added to Ethinyl Estradiol-Cyproterone Acetate in Non-Obese Women with Polycystic Ovarian Syndrome: A Randomized Controlled Study. Human Reproduction, 17, 1729-1737. https://doi.org/10.1093/humrep/17.7.1729

[26] Morin-Papunen, L.C., Koivunen, R.M., Ruokonen, A. and Martikainen, H.K. (1998) 
Metformin Therapy Improves the Menstrual Pattern with Minimal Endocrine and Metabolic Effects in Women with Polycystic Ovary Syndrome. Fertility and Sterility, 69, 691-696. https://doi.org/10.1016/S0015-0282(98)00011-9

[27] Harborne, L., Fleming, R., Lyall, H., Norman, J. and Sattar, N. (2003) Descriptive Review of the Evidence for the Use of Metformin in Polycystic Ovary Syndrome. The Lancet, 361, 1894-1901. https://doi.org/10.1016/S0140-6736(03)13493-9

[28] Cusin, I., Sainsbury, A., Doyle, P., Rohner-Jeanrenaud, F. and Jeanrenaud, B. (1995) The ob Gene and Insulin. A Relationship Leading to Clues to the Understanding of Obesity. Diabetes, 44, 1467-1470. https://doi.org/10.2337/diabetes.44.12.1467

[29] Rouru, J., Anttila, L., Koskinen, P., Penttila, T.A., Irjala, K., Huupponen, R. and Koulu, M. (1997) Serum Leptin Concentrations in Women with Polycystic Ovary Syndrome. The Journal of Clinical Endocrinology \& Metabolism, 82, 1697-1700. https://doi.org/10.1210/jcem.82.6.3996

[30] Morin-Papunen, L.C., Koivunen, R.M., Tomas, C., Ruokonen, A. and Martikainen, H.K. (1998) Decreased Serum Leptin Concentrations during Metformin Therapy in Obese Women with Polycystic Ovary Syndrome. The Journal of Clinical Endocrinology \& Metabolism, 83, 2566-2568. https://doi.org/10.1210/jcem.83.7.4944

[31] Sitruk-Ware, R. and Nath, A. (2013) Characteristics and Metabolic Effects of Estrogen and Progestins Contained in Oral Contraceptive Pills. Best Practice \& Research: Clinical Endocrinology \& Metabolism, 27, 13-24. https://doi.org/10.1016/j.beem.2012.09.004

[32] Cullberg, G., Hamberger, L., Mattsson, L.A., Mobacken, H. and Samsioe, G. (1985) Lipid Metabolic Studies in Women with a Polycystic Ovary Syndrome during Treatment with a Low-Dose Desogestrel-Ethinylestradiol Combination. Acta $\mathrm{Ob}$ stetricia et Gynecologica Scandinavica, 64, 203-207. https://doi.org/10.3109/00016348509155113

[33] Porcile, A. and Gallardo, E. (1991) Long-Term Treatment of Hirsutism: Desogestrel Compared with Cyproterone Acetate in Oral Contraceptives. Fertility and Sterility, 55, 877-881. https://doi.org/10.1016/S0015-0282(16)54291-5

[34] Mastorakos, G., Koliopoulos, C. and Creatsas, G. (2002) Androgen and Lipid Profiles in Adolescents with Polycystic Ovary Syndrome Who Were Treated with Two Forms of Combined Oral Contraceptives. Fertility and Sterility, 77, 919-927. https://doi.org/10.1016/S0015-0282(02)02993-X

[35] DeFronzo, R.A. and Goodman, A.M. (1995) Efficacy of Metformin in Patients with Non-Insulin-Dependent Diabetes Mellitus. The Multicenter Metformin Study Group. The New England Journal of Medicine, 333, 541-549. https://doi.org/10.1056/NEJM199508313330902

[36] Ehrmann, D.A., Barnes, R.B., Rosenfield, R.L., Cavaghan, M.K. and Imperial, J. (1999) Prevalence of Impaired Glucose Tolerance and Diabetes in Women with Polycystic Ovary Syndrome. Diabetes Care, 22, 141-146.

https://doi.org/10.2337/diacare.22.1.141 